\title{
Main Problems in the Innovation of Rural Financial Products and Service Modes in Hainan Province and Relevant Suggestions
}

\author{
Huifang Chen
}

Hainan College of Vocation and Technique, Haikou Hainan, 570216, China

\begin{abstract}
Keywords: Hainan Province, Rural financial products, Innovation.
\end{abstract}
\begin{abstract}
Innovation can not only inject a powerful driving force for the development of modern financial products but also is also an important determinant for the core competitiveness of modern financial products. The development of rural financial products and service modes cannot not be separated from the promotion of effective innovation in the present social atmosphere emphasizing innovation and progress. However, innovation is neither boundless nor ruleless. Actually, scientific and effective innovation should be pursued in the development process of financial products and service modes. Based on this, this paper simply analyzes the problems in the innovation work of rural financial products and service modes in Hainan province on the basis of scientific investigation and gives some targeted improvement suggestions, in the hope of enlightening the development and progress of financial products in Hainan.
\end{abstract}

\section{Introduction}

With the progress of the era and development of the society, rural areas have also become the major consumption areas of financial products. Compared with urban areas, there are a few of financial products developed and a small variety of financial products and service modes in rural areas, so the development potential in rural areas is great. Hainan Province has always attached importance to the innovation of rural financial products and their service modes so as to develop more rural financial products and service modes, enrich rural residents' financial life and provide practical financial products to inject a driving force for rural development and construction. In recent years, Hainan Province has made outstanding achievements in the innovation of rural financial products and service modes. Besides, the appearance of various emerging financial products and service modes has also made rural residents to feel the convenience of financing and the charm of finance. However, objectively, there are still some significant problems in the innovation of rural financial products and service modes in Hainan Province and reasonable improvement is needed.

\section{Introduction to rural financial products and service modes pushed out in Hainan Province}

\section{Innovation of rural financial products in Hainan Province}

There are chiefly four types of innovation of rural financial products in Hainan Province. The four types are respectively as follows: first, it is the "Yixiaotong" micro-credit loan. The "Yixiaotong" micro-credit loan has obtained rapid development in rural areas of Hainan Province. The Hainan Rural Credit Union together with Postal Savings Bank pushed out the "Flood Dragon Action" and the "Fierce Dragon Action" successively. Then, the amount of distribution, net increase and balance of "Yixiaotong" micro-credit loans have set the records of Hainan Province. Second, it is the rural faithful youth start-up loan. Jointly promoted by multiple departments such as Hainan Youth League Committee, Haikou Central Sub-branch and Hainan Rural Credit Union, the rural faithful youth 
start-up loan develops very fast. The implementation effect in Lingshui County is the best and the rural faithful youth start-up loan balance here has reached a new high level. Third, it is the new rural construction loan, which was pushed out by Hainan Agricultural Development Bank, aims to provide funds for rural land reclamation, construction of rural centralized housing, construction of small towns and other products and has reached a satisfactory effect. Fourth, it is the "Sudaitong" product, which was pushed out Hainan Branch of China Construction Bank. The credit business is implemented via full-amount mortgage guarantee. The pushout of the product has formed the "bank+ guarantee corporation +enterprise + peasant" innovative financial product service mode, which effectively promotes the development and progress of rural economy.

\section{Rural financial service modes in Hainan Province}

There are chiefly two types of innovation of rural financial service modes in Hainan Province. The two types are respectively as follows: first, it is the "financial service for the convenience of people" EPOS project of the Rural Credit Union. In the "financial service for the convenience of people" EPOS system of the Rural Credit Union, more than two thousand of terminals have been newly increased in villages and towns of Hainan Province and there are accumulatively more than seven thousand EPOS terminals in villages and towns so that the vast people in villages and towns can benefit from them. Based on the good terminal construction and service mode, the trading condition of the "financial service for the convenience of people" EPOS system of the Rural Credit Union is in good condition, and both the terminal coverage and trading volume rank first in Hainan Province. Second, it is the Huilong Card of Agricultural Bank of China and the Huilong Card of Rural Credit Union. The Huilong Card of Agricultural Bank of China was developed by Hainan Branch of Agricultural Bank of China and integrates credit loans, residents' wealth management, consumption settlement and agent service. Besides, there is no need to pay the charge for opening a card and small-amount account management fee, and only halved annual fee is paid directly, so peasants reduce the actual expenses on card and can feel the convenience and practicalness of modern financial service. The Huilong Card of Rural Credit Union was developed by Hainan Rural Credit Union. After changing the original step-by-step financial payment mode, the financial payment flow has been greatly simplified and it is ensured that all sorts of fees can arrive at the peasants' cards directly, so that common peasants can enjoy the material benefits from financial service [1].

\section{Main problems in the innovation of rural financial products and service modes in Hainan Province}

Remarkable achievements have been made in the innovation of rural financial products and service modes in Hainan Province but there are still some problems to be solved. The analysis is shown below.

\section{Inclination of divorcing from agriculture in some county financial institutions}

Some county financial institutions in Hainan Province concentrate more efforts in large loans, mass organization loans and syndicated loans and neglect micro-credit peasant loan business, so there is the inclination of divorcing from agriculture. As the rural micro-credit loans are characterized by high cost, low income and high risk, some county financial institutions are not willing to provide too many rural micro-credit loans. As a result, the release of county financial products shows a peasant-divorcing and large-borrower tendency. On the one hand, the micro-credit loan balance for peasants declines year by year and there is a significant peasant-divorcing and non-localization trend of loans in county financial institutions so that peasants cannot continue to obtain sufficient micro-credit loans. On the other hand, the sharply increasing volume of large loans, long-term loans and concentrated loans occupies a growing proportion in the total loan amount of county financial institutions and further compresses the business space for micro-credit loans for peasants. 


\section{Unsatisfactory construction effect of rural mortgage guarantee system}

It is found through investigation that the construction of government guarantee systems of all counties in Hainan Province obviously lags behind and the construction of mortgage guarantee registration intermediary system is also delayed again and again, objectively resulting in the increases in agricultural loan risk and cost, significant conflicts with the operating benefits of financial institutions, and a great obstruction for the development of rural financial products. Although Hainan Government made investment to organize all cities and counties to establish guarantee corporations and guarantee centers, such corporations and centers in many places are dismal in businesses and even are closed down because they are restricted by many factors such as capital, finance and modes. Besides, guarantee corporations and guarantee centers in many places encounter the problem of guarantee fund shortage. All of them have exerted negative influences on the development of agricultural mortgage guarantee system and also have led to the difficulty in realizing micro-credit loans for peasants by means of guarantee.

\section{Service authority and talent restriction in the rural financial innovation}

The rapid development of rural financial products needs the basic rural financial institutions to have enough loan approval authority and adequate talent support, both of which are not achieved in the process of innovation of rural financial products and service modes in Hainan Province. From the perspective of business authority, provincial financial institutions have the authority to research, develop and popularize financial products but are strictly supervised and have limited scope of business, so they are not highly enthusiastic toward innovation. Although county financial institutions are close to the market and common peasants, they encounter a great innovation obstruction because they are severely retrained by loan approval authority. From the perspective of talents, both provincial and county financial institutions are faced with the problem of severe shortage of financial innovative talents, and their existing talents have poor theoretical basic skills, lack enough experience in financial product management and also lack the innovation ability [2].

\section{Suggestions for facilitating the innovation of rural financial products and service modes in Hainan Province}

With respect to the innovation of rural financial products and service modes in Hainan Province, there is still a long way to go. Based on the current situation of rural financial products and service modes in Hainan Province, some innovation suggestions are given here to better promote the innovative development of rural financial products and service modes in Hainan Province.

\section{Establish an effective incentive mechanism to promote county financial institutions to support agriculture}

As the micro-credit loans for peasants characterized by high cost, high risk and low income, many county financial institutions in Hainan Province are reluctant to provide peasants with micro-credit loans. Therefore, it is required to establish a good incentive mechanism to effectively encourage county financial institutions and promote them to provide more and more effective peasant-oriented micro-credit loan businesses and thus accelerate the rural economic development. On the one hand, it is required to strengthen the supervisory mechanism. According to the practical condition of micro-credit loans for peasants, establish the micro-credit loan classification standards for county residents and small enterprises, perfect risk weight, special provision withdrawal and other assessment indexes and promote the scientific development of micro-credit loans of county financial institutions with a good micro-credit loan mechanism. Besides, achieve the long-term sustainable development of peasant-oriented micro-credit loans of county financial institutions through the combination of various financial tools so as to meet county financial institutions need of making profits. On the other hand, it is required to strengthen the government incentive. The government 
shall enlarge the investment in administrative and financial resources regarding "three agriculture" finance; the government departments concerned should painstakingly take effective measures, introduce refined policies, increase rewards for agriculture-related loans, reduce the obstacles for agriculture-related loans, increase the compensation for agriculture-related loan risk and increase the deduction from income tax so as to create a favorable external environment for county financial institutions to provide peasant-oriented micro-credit loans and effectively arouse the county financial institutions' enthusiasm about “agriculture-support” loans. In addition, a good synergy should be formed between the government mechanism and financial institution mechanism. The government's incentive mechanism should uses the financial institutions' loan mechanism as the essential basis while financial institutions' loan mechanism should be well connected to the government's incentive mechanism based on the government's policies and gain most benefits from the government's incentive mechanism. In this way, the benign implementation of financial institutions' “agriculture-support” loans can be promoted effectively.

\section{Promote the good construction of rural credit guarantee system}

The rural credit guarantee system is the foundation and precondition for the county financial institutions to trustingly and boldly offer micro-credit loans to peasants, so it is of vital importance to promote the construction of rural credit guarantee system. On the one hand, in combination with the current situation of construction of rural credit guarantee system, release relevant preferential policies; emphatically reduce or exempt the guarantee corporations' taxes related to loans serving peasants and agricultural enterprises; when guarantee corporations painstakingly keep business going and encounter great operating obstacles, give assistance to guarantee corporations, meanwhile, introduce nongovernmental capitals, especially local leading enterprises, to set up "three agriculture" guarantee corporations, thoroughly reorganize existing guarantee corporations in all cities and counties and encourage the good mutual cooperation among guarantee corporations so as to enhance their actual guarantee ability and business level. On the other hand, widely carry out the experimental work about land, forest ownership, authentic homestead right, registration, certificate awarding, mortgage \& pledge, arbitration system and construction of transshipment center etc. around Hainan Province; conduct scientific inspections for the effect of work innovation and accumulate rich pilot project experience by using pilot projects; on this basis, promote the scientific and efficient circulation of agricultural rights in all cities and counties; encourage the reasonable implementation of modes of operation in various forms and proper scales to gradually improve the agricultural benefits. Innovate in the varieties of agricultural right mortgage credit, use the agricultural right in a good, flexible and effective way and make efforts to reduce credit risks so as to greatly improve county financial institutions' risk guarantee ability for micro-credit loans for peasants.

\section{Reasonably distribute authority and painstakingly train talents to promote rural financial innovation}

At present, financial institutions have limited authority and lack talents, it is the inevitable need of rural financial innovation to reasonably distribute authority and make efforts to train talents. On the one hand, redistribute the service authority of rural financial innovation. At present, the innovation authority of financial products of commercial banks in Hainan is highly centralized in the head office. However, there are few associations among the head office, actual rural loan borrowers and enterprises and they lack mutual understanding, so it is likely to cause the divorce between the innovation of rural financial products and rural bandwidth demand. Therefore, it is suggested that the Hainan Commission of Head Offices and Banking Regulatory Commission coordinate the major agriculture-related financial institutions such as Agricultural Development Bank, Agricultural Bank of China and Postal Savings Bank, reasonably transfer the innovation authority of rural financial products of head offices of all commercial banks in combination with the current situations of rural economy, characteristics of rural economy and local natural endowment advantages in all places, give 
play to the local advantages and enthusiasm in the innovation of rural financial products and utilize better ways to distribute the innovation authority of financial products so that the local financial institutions can make outstanding achievements in the innovation of financial products. On the other hand, make efforts to train financial innovation talents for banking institutions in a planned way. Actively employ and comprehensively train financial innovation talents who have rich specialized knowledge and some experience and help them to give play to their innovation ability for innovation of financial products; actively conduct the education of financial innovation idea for front-line credit extension employees, help all front-line credit extension employees to recognize the value and significance of financial innovation and make all front-line credit extension employees to devote themselves to the innovation of financial products and financial service on the premise of completing their own work well; establish internal innovation incentive mechanism for banks, connect innovation with employees' salary and reward employees with high innovation enthusiasm and satisfactory innovation results so as to arouse other employees' innovation enthusiasm in financial products [3].

\section{Conclusion}

The innovation of rural financial products and service modes significantly facilitates the rapid development of rural economy, helps financial institutions to form an impeccable rural credit service mechanism and realize the good butt joint with peasants and small local enterprises. Hainan Province has made fruitful innovations in rural financial products and service modes, made outstanding achievements in innovation, helped peasants and small local enterprise to obtained more micro-credit loan supports and inject new vigor and driving forces to the development of rural and local economy. Problems during the innovation of rural financial products and service modes in Hainan Province cannot be divorced from the current situation of rural areas. To some extent, such problems are also the problems easily arising in the innovation of nationwide rural financial products and service modes. The improvement in the innovation of financial products and service modes in Hainan Province will bring about brand-new opportunities for the development of rural economy in Hainan Province, promote the good and sustainable development of rural economy in Hainan Province, and also give some favorable enlightenment for the development of rural financial products and service modes in other areas.

\section{References}

[1] Xu Dandan. Research on the Problem of Sustainable Development of Rural Finance in China. Jilin University, 2013.

[2] Peng Yan. Study on the Innovation of Rural Financial Products and Service Innovation. Northwest A\&F University, 2015

[3] Fu Jiao. Demand-oriented Study on the Innovation of Rural Financial Products. Xiangtan University, 2014. 